publications came to be fully appreciated by those who had to restart the Ordnance Survey on its national work after the Second World War. With many files and records destroyed during the War and a seven years gap in the continuity of the work, the existence of those carefully prepared historical studies was an inestimable boon. In 1935, having reached the age limit, Winterbotham retired from the Army and from the Ordnance Survey. In the same year he was made a C.B.

But the energy which had so far been mainly directed to the execution of his official duties was now more fully available for that work for the International Union of Geodesy and Geophysics which had always been one of his principal interests. In the early general assemblies of the Union his professional co-operation had been much in demand by the Governments he had advised and assisted in survey work. At the third assembly in Prague (1927), we find him entrusted with the representation of South Africa, Australia and Canada, as well as the General Staff of the War Office.

Then in 1928, when Colonel (later Sir Henry) Lyons succeeded Sir Arthur Schuster as general secretary of the International Research Council and resigned the general secretaryship of the International Union of Geodesy and Geophysies, Winterbotham accepted an invitation to succeed him; and from the following assembly at Stockholm in 1930 until his death, Winterbotham's interests and enthusiasms were seldom far from the Union. There he guided and humoured successive presidents and executive committees and helped the secretaries of the constituent associations not quite so experienced or so expert in administrative matters as himself-all with a friendly kindliness which did not stop him from frank expression of opinion when he considered the real interests and welfare of the Union to be at stake.

Winterbotham's wide experience of men and affairs stood the Union in excellent stead during the war years. Immediately after the Washington assembly in September 1939, from which he was recalled for official duties, Winterbotham took steps to safeguard the international interests and widely distributed funds of the Union and of its various associations. It is largely owing to his judgment and foresight that the International Union of Geodesy and Geophysies came through the war years ready to undertake fresh international scientific work. Meanwhile he had offered his services to the Government and had been employed, first as chief instructor in survey at the School of Military Engineering, and later under the Admiralty on the preparation of topographical reports.

Before the War had properly ended, Winterbotham set about gathering together again the broken threads of international geodetic and geophysical collaboration. At a meeting of the executive committee of the Union which he was instrumental in calling together in 1945, plans were discussed for early renewal of the Union's activities. By that time, unfortunately, Winterbotham had been advised that he must take things more easily, and it was with great regret that the committee accepted his resignation. At the subsequent extraordinary assembly of the Union in August 1946, Winterbotham was honoured by election as one of the two vice-presidents of the Union under the new statutes in the framing of which he himself had spent much thought and care. By this election the assembly hoped that his ripe experience and judgment in Union affairs would continue at the disposal of the Union for many years ; but, though not known to many, he was already a sick man, and he did not live to contribute still further to the Union's international prestige, which he had done so much to enhance during his long and active association with it.

There will be many people in many lands who will remember Winterbotham's sage counsel given in a characteristic and incisive style, and there will be many who will miss that counsel in the years to come. He leaves a widow, one son and two daughters.

G. Cheetham

\section{Dr. C. T. Madigan}

By the death of Cecil Thomas Madigan, Australian geology has been deprived of one of its most colourful personalities, a man who throughout his entire life had retained the youthful spirit of the true pioneer and explorer. Born on October 15, 1889, the son of Thomas Madigan of Renmark, South Australia, he was educated at the University of Adelaide, where he was known as a first-class oarsman.

Although elected to a Rhodes Scholarship at Oxford in 1911, Madigan did not go into residence until 1914, in the meantime having accompanied Sir Douglas Mawson as his second-in-command on the Australian Antarctic Expedition. On the outbreak of war not long after his arrival in Oxford, he was granted a commission in the Royal Engineers, with whom he saw four years service in France, being twice wounded and gaining a mention in dispatches.

On demobilization in 1919, Madigan returned to Oxford and obtained a first-class in the final honour school of geology. While carrying out research on material brought back from the Antarctic, he was appointed assistant Government geologist in the Sudan, where he spent two years before returning to Adelaide to become senior lecturer in geology, a post he held until his death. During the Second World War Madigan again joined the Forces, and with the rank of lieutenant-colonel was chief instructor of the School of Military Engineering at Liverpool, New South Wales, for three years.

The greater part of Madigan's work was devoted to the exploration of what Gregory had aptly termed the "Dead Heart of Australia". In 1929 he made the first aerial reconnaissance of this terra incognita, exploring an area of some 28,000 square miles which no white man had ever seen and which had previously baffled all attempts to cross it. He proved that the great lakes were dry, and that nothing lay within the area other than clay-flats encrusted with salt and everlasting sand-ridges; having had, in his own words, the somewhat melancholy satisfaction of saving the danger and expense of further exploration.

By this and subsequent journeys with car or camels, Madigan obtained a vast amount of valuable geological and topographical information, extending as far north as the MacDonnell Ranges and the area north of Lake Eyre, which he named the Simpson Desert; and the account he has given of this most inhospitable country in numerous papers published by the Royal Society of South Australia, the Royal Geographical Society and the Geological Society of London makes the most interesting reading. Some of his remarkable aerial photographs were recently published in the Illustrated London News (January 25, 1947). 
In 1915 Madigan married Wynnis Wollaston, by whom he had three sons and two daughters, all of whom survive him. While grieving his loss, his many friends may be comforted by the thought that one who loved the wide open spaces was spared possibly many years of enforced inactivity. He has left behind a record of service to his country of which any man might well be proud. J. A. Douglas

\section{Prof. P. J. Daniell}

Prof. P. J. DANIELL, professor of mathematics in the University of Sheffield, died on May 25, 1946, at the age of fifty-seven. He was educated at King Edward VI School, Birmingham, and at Trinity College, Cambridge. He was Senior Wrangler in 1909 , the last year in which the names of the candidates in Part 1 of the Mathematical Tripos were placed in order of merit. In Part 2 of the Natural Sciences Tripos in 1910 he obtained a first class, and in 1912 he was awarded a Rayleigh Prize. After studying in Göttingen for two years and then acting as an assistant lecturer at the University of Liverpool, he went to the Rice Institute, Texas, where he was professor of mathematics until 1923. In that year he returned to England as professor of mathematics in Sheffield, and held this post until his death. In the summer of 1945 he had a serious illness from which he did not fully recover, and he died about a year later after a sudden relapse.

Prof. Daniell was a distinguished scholar of pure and applied mathematics. The most important of his earlier contributions to mathematical knowledge were related to generalized integrals and derivatives. He extended the Radon-Young integral to space of an infinite number of dimensions, and his integral was applicable, for example, in the theory of functionals. $\mathrm{He}$ considered also generalized derivatives, using methods that were based partly on Young's work in one dimension and partly on ideas introduced by himself. His research, however, extended over a wide field of applied science, and much of his $t$ me and energy were spent in assisting and advising research workers in a variety of problems. His mathematical investigation on the propagation of flame motion, for example, was related to experimental work carried out by the Safety in Mines Research Board in Sheffield. Perhaps his most important work of this kind was that done during the War, when he was engaged in problems arising from the control of instruments designed to pick up and locate targets such as aeroplanes and ships. $\mathrm{He}$ assisted in the work of improving the performance of such instruments, and he was a leading exponent of the frequency response approach to the problems involved in the design of these instruments. He initiated methods in dealing with problems of back-lash, and he assisted the Admiralty in ultra-high-frequency detection methods.

In educational affairs generally, Daniell took an active share in addition to his university activities. $\mathrm{He}$ was the representative of the University of Sheffield for more than twenty years on the Joint Matriculation Board, and took a significant part in shaping its policy.

His death means a great loss to the mathematical world, but he is especially missed in the University of Sheffield, where his experience and wisdom would have been of great value in guiding the developments now in progress.

\section{NEWS and VIEWS}

\section{Library of Sir James Hall, Bart., of Dunglass, Haddingtonshire}

In the last week of February, Messrs. Hodgson and Co., of Chancery Lane, London, offered for sale the library accumulated at Dunglass House, in East Lothian, in the latter half of the eighteenth and the earlier part of the nineteenth century by Sir James Hall (1761-1832), the distinguished geologist, and other members of his family. The collection contained many early and important works in various branches of science and in medicine, but was of more particular interest on account of the geological works included. Hall was a pioneer in experimental geology, and carried out a number of classic laboratory experiments devised to support some of the conclusions reached by his friend James Hutton, from general reasoning based on geological field work, and embodied by the latter in his "Theory of the Earth". One series of experiments was designed to show that molten basalt lava, when cooled slowly, forms a stony or crystalline mass comparable with the basalt occurring in Nature, rather than a vitreous mass, as was usually contended at that time. The second and more famous series was instituted to determine the combined effects of heat and pressure on carbonate of lime, the problem being to find out if powdered chalk could be converted into firm limestone or into marble by heating in a confined space. Hutton's view that marble would result was based on geological grounds, but was apparently at variance with experimental facts, as then known. Some preliminary trials were carried out during Hutton's lifetime, but a more prolonged and systematic series of experiments was not commenced until after the latter's death, having been postponed in deference to his marked disapproval of those who "judge of the great operations of the mineral kingdom by kindling a fire and looking into the bottom of a crucible".

The main experiments, which proved entirely successful in their object, were carried out during the period 1798-1805; and full details were recorded by Hall, in the form of a diary, in two folio volumes. These are the volumes which appeared in the sale room as Lot 98, bearing the title "Chemical Experiments made with a view to Obviate some of the Difficulties in Dr. Hutton's 'Theory of the Earth'". It is a matter for satisfaction to be able to record that these diaries were purchased by Messrs. Quaritch on behalf of the National Library of Scotland, where they will now find a permanent and appropriate resting place. Among other works of interest sold, the writings of James Hutton were well represented, not only by his lesser-known books, but by two copies of his famous "Theory of the Earth". The publication of this book, in 1795, has long been recognized as a landmark in the history of geology. The prices obtained, $£ 110$ for one copy and $£ 95$ for the second, reflect not only its scientific importance but also its great rarity. 